\title{
Spatial Econometric Model for Economics Development in Archipelago of Riau, as a Defense System Development in Republic of Indonesia
}

\author{
Susanti Linuwih ${ }^{1}$, Setiawan ${ }^{1}$, Dwiatmono A. $\mathrm{W}^{1}$, and Wiryadi ${ }^{2}$
}

\begin{abstract}
Province of Archipelago of Riau is a region in Indonesia which is adjacent to Singapore and Malaysia. This province has a great potential conditions diversity and natural resources. Planning on public prosperity improvement is necessary in order to increase loyalty and nationalism to Republic of Indonesia. The aim of this research is to build a spatial econometric model of economic growth in Province of Archipelago of Riau. One of the results shows that in recent 4 years Batam always gives the largest contribution to GRDP in Province of Archipelago of Riau. This can be understood that the contribution is more than $\mathbf{7 2 . 0 \%}$ not only based on GRDP at current prices, but also based on GRDP at constant prices. Economic growth rate in regions in Province of Archipelago of Riau is higher than national economic growth rate. The model fits well because the coefficient of determination $R^{2}$ is more than $85 \%$. There are only 3 worse models, i.e. based on building construction in Batam (with $R^{2}=59.6 \%$ ), in Tanjungpinang (with $R^{2}=74.0 \%$ ), and based on transportation and communication in Tanjungpinang (with $\mathbf{R}^{2}=37.1 \%$ ).
\end{abstract}

Keywords - Growth model, spatial econometric

\section{INTRODUCTION}

A rchipelago of Riau, as one of archipelagos in Indonesia, shows a great diversity of condition and natural resources. Area which is not government administration area in Archipelago of Riau is dominated by many small islands and some big islands, which also have a high accessibility to international market such as Singapore and Malaysia. Besides that, this archipelago has a great potential of natural resources in oil and fishery. On the other side, geographically there are 2 big groups of island, i.e. Batam and the surrounding islands, which are close to Riau, and Archipelago of Natuna, which are close to Kalimantan. The local economy is dominated by agriculture. Agriculture in Archipelago of Riau contributes $88 \%$, while in Batam it does $31 \%$. Industries develop more around Batam, because industries in the other regions only contribute $1-2 \%$.

Based on National Space and Territory Planning (Rencana Tata Ruang dan Wilayah Nasional), there are 2 reliable regions, i.e. Batam and Natuna. Batam and the surroundings have potency in industries, mining, and

${ }^{1}$ Susanti Linuwih, Setiawan, and Dwiatmono A. W. are with Department of Statistics, FMIPA, Institut Teknologi Sepuluh Nopember, Surabaya, 60111, Indonesia. Email: susanti_1@statistika.its.ac.id.

${ }^{2}$ Wiryadi is Research Development Institution Staff, Department of National Defense, Jl. Jati No. 1 Pondok Labu, Jakarta Selatan, 12450, Indonesia. tourism. Location proximity to international market such as Singapore brings advantages for industry and service development in Batam. This region is planned to be a free trading area, where certain taxes are not taken. There have been predicted that in Archipelago of Anambas (around Batam) there are 5.5 billion $\mathrm{m}^{3}$ granites and 18 million $\mathrm{m}^{3}$ quartz, andesitic, basal, and half-diamond. This region is also potential for tourism. Some tourism objects which can be developed are marine tourism objects, such as sailing, beaches, surfing, and diving in Bintan island. Based on UU no. 22/2009 about Local Government, local government has the rights to manage seashore natural resources including the development of marine and seashore tourism objects. This effort is necessary done continuously without disobeying public needs and harming sea ecosystem and the surroundings. Also, surely it should bring new work field for local people.

Natuna has a great potency for mining, fishery, and agriculture. Alternative for oils is found in this region and at the present time, some foreign companies do the exploration. Fishery in this region includes inland fisheries, fishing pond, and marine fisheries. Because Natuna is an archipelago which is surrounded by ocean, Natuna has a great potential for marine fishery. The most suitable plant planted in this region is coconut trees.

Two regions, i.e. Batam and Natuna, which are geographically located far apart, could reduce the economic linkage between both regions. Batam and the surroundings tend to be related to Riau and Singapore, while Natuna is close to Kalimantan and Sarawak. Coercive linkage among regions in Archipelago of Riau could reduce effectiveness and efficiency of local region development [11].

The development of Archipelago of Riau as a development of defense system can be done by forming the defense posture. The posture of national defense is the form of national defense showing the power, ability, and defense power in a country.

The posture of national defense is built and prepared earlier by the government. The development of the posture of military defense is in the control of Minister of National Defense. The development of the posture of non military defense becomes the responsible of the government through the coordination among ministers/the institution head of non department governor and Minister of National Defense.

The posture of non military defense is the reflection of the national resources development result. The elements of non military defense are in the rights and the responsible of every government institution besides Department of National Defense, which is done through 
the improvement of every sector with the coordination of Minister of National Defense.

The development for military and non military defense is the optimization of the national development by considering all influencing factors. Prosperity approach for improving public lifestyle and security approach support the stability in politics, economics, socials, and security defense. The combination of military and non military defense is defined as the improvement of public life rate and the security from military and non military threats so that the sustainable development occurs. For arranging the development model based on national defense, the military and non military issues in the Province of Archipelago of Riau is necessarily understood, especially by the local government which is Regional Government of Archipelago of Riau.

Bappenas (2007) brought some conclusions by using econometric model, such as:

1. Government fiscal policy about raising the capital expenditure will affect on the improvement of macro economics, both in nation and region. The improvement is shown by the raise of the national Gross Domestic Product (GDP) of $2.32 \%$. The raise of GDRP will affect on the increase of the employees, which then it will decrease the number of the unemployment in the urban areas and the cities. Besides that, the poverty rate will also decrease.

2. The improvement of expenditures of product and services will give a good effect on the raise of the national and regional products. The increasing expenditures of product and services will also bring new work fields for each sector. Industry sector gives the most work fields.

3. The improvement of employee expenditures will cause the raise of products which is shown by GDP and Gross Regional Domestic Product (GRDP). The policy of the improvement will also give a positive impact on the addition of the work fields, the diminishing poverty rate, and the local revenue in each province with different units.

4. The target of the GRDP growth $5 \%$ in the period 2000-2005 can be reached by increasing the capital expenditures by $5.67 \%$, the expenditures of product and services by $5 \%$, and the employee expenditures by $5 \%$. But, the scenario of this fiscal policy brings a different impact on the raise of GRDP in each region.

5. The target of GRDP growth 5\% in 2006-2010 hopefully can be reached by using the combination of the fiscal policy, i.e. by increasing $5 \%$ of the capital expenditures, $3.5 \%$ of the expenditures of product and services, and $2 \%$ of the employee expenditures.

Based on the policy analysis and simulation which are arranged based on the historical data and the prediction, it can be generally concluded that government expenditure effectiveness in increasing regional economic growth, reducing the number of unemployment, and reducing the poverty rate is determined by the size and the kind of the government expenditure, the regional priority sector, and the regional priority. Therefore, the optimum and the suitable government expenditure should be decided carefully and fully-understood in order to get a good impact on GRDP of all regions in the country.

From the background of the research, the aim is to build a spatial econometric model of economic growth in
Province of Archipelago of Riau based on the national defense.

Based on the econometric model, it can be figured out that investment in any sector should be improved in order to increase economic growth. The economic growth in a region is an indication of the welfare of residents in the area. Welfare approach is one attempt to create a regional defense and security.

\section{THEORIES}

\section{A. Econometric Model}

Econometrics is a social knowledge integrated from economics, mathematics, and statistics. The purpose of econometrics is testing the significance of economics theories such as the relation among economic variables quantitatively by using empirical data. Econometrics model in the form of simultaneous equation system can be used for economic growth analysis.

Research on applied econometrics is related to parameter measurement of relation between economic variables or prediction based on economic variables. Econometric model which illustrates the relation among economic variables is often simple, such as single equation; but, it often consists of some equations which are simultaneous (simultaneous equation system). There are 4 steps in econometric research, such as (i) model specification, (ii) model estimation, (iii) model evaluation, and (iv) prediction evaluation. In the specification step, the model is built specifically to follow the corresponding phenomenon. Because the phenomenon is complex, the model should be spatial simultaneous equation system due to the relation among local, national, and international areas. In the model estimation, the suitable method is spatial 3-SLS method.

After the model is built by using the suitable estimation method, the model is evaluated. The model evaluation is the third step. The best model should fit economic criteria (size and signs), statistics criteria (goodness of fit), and econometric criteria. In the last step, the model is used for prediction and evaluation of the present regulation. Evaluation of the present regulation can use a scenario or simulation. The important step in econometrics is making the model specification or making the model formulation specifically about the economic phenomenon. There are 3 things should be noticed in making the model formulation, such as (i) the variables in the model, (ii) size and signs of the model parameters, and (iii) the mathematical equation of the model.

Specific understanding about the condition and potency is necessary to make a model which can illustrate the economic growth, then the model can be used well to improve the economics in Province of Archipelago of Riau. Economic growth in a region can be measured by the growth of GRDP. GRDP consists of 9 sectors, i.e:

1. Agriculture,

2. Mining,

3. Industry,

4. Electricity, gas, and water,

5. Building construction,

6. Trades,

7. Transportation and communication,

8. Monetary institution, and

9. Public services. 
On the other side, there always be a certain sector which is prioritized based on the regional potency. In Archipelago of Riau, there are 2 reliable areas, i.e. Batam and Natuna. In Batam, there are 4 potencies which need to develop, i.e. (1) industry, (2) mining, (3) tourism, and (4) services. Therefore, these 4 sectors are simulated by the economic growth model for this region. In Natuna, there are 3 reliable sectors, i.e. (1) mining, (2) fishery, and (3) agriculture.

\section{B. Spatial Econometrics}

Spatial econometrics is a weighted regression model which weight is a location factor. Closeness and correlation among locations cause the appearance of spatial autocorrelation. Spatial econometrics is an improvement of simple regression model which accommodates spatial autocorrelation existence. Generally, spatial model based on [1] is as follows:

$$
\left.\begin{array}{l}
\mathbf{y}=\rho \mathrm{W} 1 \mathrm{y}+\mathrm{X} \beta+\mathrm{u} \\
\mathrm{u}=\lambda \mathrm{Wu}+\varepsilon \\
\varepsilon, \mathrm{u}=\lambda \sim \mathrm{N}\left(0, \sigma^{2} \ln \right)
\end{array}\right\}
$$

where $\mathbf{y}$ is a px1 dimensional vector, $\rho$ is coefficients of lag spatial dependent variable, $u$ is a vector of error, and $\mathrm{W}$ is weight matrix with $\mathrm{nxn}$ dimension, $\beta$ is $\mathrm{kx} 1$ dimensional vector, $\mathrm{X}$ is nxk dimensional matrix, and $\lambda$ is coefficients for spatial autoregressive structure for disturbance $u$.

One of the spatial effects which occur for crosssectional data is the existence of spatial autocorrelation. Spatial autocorrelation which is also known as spatial dependence can be divided into 2 kinds, such as spatial lag and spatial error. Spatial dependence occurs because of the interdependence among regions in the crosssectional data. In this research, the model is spatial lag model in order to know the amount of GRDP per region or per city. Some explanation about spatial lag and spatial error are:

\section{Spatial Lag Model}

From Eq. (1), a model can be made by using certain restriction. If $\lambda=0$, then:

$\mathrm{y}=\rho \mathrm{W} 1_{\mathrm{ij}}$ then, $\mathrm{y}+\mathrm{X} \beta+\mathrm{u}$

$\mathrm{u}=\varepsilon$

This model is a mixed regressive-spatial autoregressive model which has spatial dependent variable lag 1.

2. Spatial Error Model

If $\rho=0$, then,

$\mathrm{y}=\mathrm{X} \beta+\mathrm{u}$,

$\mathrm{u}=\lambda \mathrm{Wu}+\varepsilon$, maka $\mathrm{u}(1-\lambda \mathrm{W})=\varepsilon$

$(1-\lambda W) y=(1-\lambda w) X \beta+(1-\lambda W) u$

$\mathrm{y}=\lambda \mathrm{Wy}+\mathrm{X} \beta-\lambda \mathrm{WX} \beta+\varepsilon$

This model is a linear regression model which is known as spatial autoregressive disturbance model.

\section{Spatial Weighting Matrix}

Spatial Weighting Matrix (W) can be obtained from neighborhood distance information. In the other words, it is from distance between one region and another. There are some methods to define contiguity among the regions. Based on [10], the method is as follows:

1. Linear Contiguity

This defines $\mathrm{W}_{\mathrm{ij}}=1$ for region on the left or right edge of the concerned region, $\mathrm{W}_{\mathrm{ij}}=0$ for the others.

2. Rook Contiguity
This defines $\mathrm{W}_{\mathrm{ij}}=1$ for region which common sides to the concerned region, and $\mathrm{W}_{\mathrm{ij}}=0$ for the others.

3. Bishop Contiguity

This defines $\mathrm{W}_{\mathrm{ij}}=1$ for region which has common vertex with the concerned region, and $\mathrm{W}_{\mathrm{ij}}=0$ for the others.

4. Double Linear Contiguity

This defines $\mathrm{W}_{\mathrm{ij}}=1$ for 2 entities which is located on the left and right side of the concerned region, and $\mathrm{W}_{\mathrm{ij}}=0$ for the others.

5. Double Rook Contiguity

This defines $\mathrm{W}_{\mathrm{ij}}=1$ for 2 entities on the left, right, north, and south side of the concerned region, and $\mathrm{W}_{\mathrm{ij}}$ $=0$ for the others.

6. Queen Contiguity

This defines $\mathrm{W}_{\mathrm{ij}}=1$ for entity which has common side and common vertex with the concerned region, and $\mathrm{W}_{\mathrm{ij}}=0$ for the others.

\section{Cobb-Douglas Model}

Cobb-Douglas model is a model which is often found in econometric analysis. Cobb-Douglas model is not linear, which means that the function is not a straight line. But, by using transformation $\mathrm{ln}$, the model becomes linear. Cobb-Douglas model is as follows:

1. If there is only one independent variable, then $Y=\beta_{0} X^{\beta_{1}} e^{\varepsilon}$

2. If there are 2 independent variables, then $Y=\beta_{0} X_{1}^{\beta_{1}} X_{2}^{\beta_{2}} e^{\varepsilon}$

The model can be made linear by using transformation ln, so the model becomes:

$\ln (Y)=\ln \left(\beta_{0}\right)+\beta_{1} \ln \left(X_{1}\right)+\beta_{2} \ln \left(X_{2}\right)+\varepsilon$

If $\ln (Y)=Y^{*} ; \ln \left(\beta_{0}\right)=\beta_{0}{ }^{*}, \ln \left(X_{1}\right)=X_{1}{ }^{*}$, and $\ln \left(\mathrm{X}_{2}\right)=\mathrm{X}_{2}{ }^{*}$ hence, the model becomes: $Y^{*}=\beta_{0}{ }^{*}+\beta_{1} X_{1}{ }^{*}+\beta_{2} X_{2}{ }^{*}+\varepsilon$

The coefficient of regression model is the elasticity, which means how many percent the dependent variable changes due to $1 \%$ change of the independent variable. Mathematically, elasticity in economics is formulated as the following:

$E_{X_{1}}=\frac{M P_{X_{1}}}{A P_{X_{1}}}$

where $A P_{x i}$ is the average product for input $X_{I}$ which can be calculated by using:

$A P_{X_{1}}=\frac{Y}{X_{1}}$

therefore, the product elasticity for $X_{1}$ can be counted by using the following:

$E_{X_{1}}=\beta_{1}$

\section{METHOD}

The The data for this research is a secondary data which is taken from Statistics Indonesia in Province of Archipelago of Riau. The data is from 2003 to 2007 [38]. The model is as follows,

$\mathrm{y}_{\mathrm{ij}}=\beta_{0} \mathrm{x}_{\mathrm{ij}}^{\beta_{1}} \varepsilon_{\mathrm{ij}}$

where

$\mathrm{y}_{\mathrm{ij}}=$ the amount of GRDP for sector $i$ in region $j$

$\mathrm{x}_{\mathrm{ij}}=$ the amount of credit for sector $i$ in region $j$

There are 9 sectors which construct GRDP, i.e.:

1. Agriculture,

2. Mining,

3. Industry, 
4. Electricity, gas, and water,

5. Buildings,

6. Trades,

7. Transportation and communication,

8. Monetary institution, and

9. Public services.

In Province of Arch. of Riau, there are 6 regions, i.e. (1) Karimun, (2) Bintan, (3) Natuna, (4) Lingga, (5) Batam, and (6) Tanjungpinang. Least square method is used for the parameter estimation.

\section{RESULTS}

\section{A. The Development of National Defense}

The development of Archipelago of Riau through the defense system can be done by integrating the military power, ability, and defense, also the non military power, ability, and defense. The posture of national defense which is built and prepared earlier by the government, both military and non military defense, is the reflection of national resources development. The elements of non military defense are in the rights and the responsible of every regional institution besides Department of National Defense. Therefore, the posture development of non military defense becomes the responsible of every department or every non-department government institution, which implementation is through the development of every sector with the coordination of Minister of National Defense.

Prosperity approach for improving public daily life level and security approach for supporting the stability of every sector is the form of development based on the defense system. The combination of prosperity and security approaches is defines as the development for improving public daily life level and the safety from every threats, both military and non military threats. Therefore, the sustainable development occurs.

Economic growth in a region can be known by the growth of the GRDP. Cobb-Douglas model is used because the coefficient can be used to interpret the elasticity. With the limited data, the economic growth models are built and shown in Table 1. Based on the estimation, the model fits well because the coefficient of determination $\mathrm{R}^{2}$ is more than $85 \%$. There are only 3 bad models, such as model for building sector in Batam $\left(\mathrm{R}^{2}=\right.$ $59.6 \%)$, building sector in Tanjungpinang $\left(\mathrm{R}^{2}=74.0 \%\right)$, and transportation sector in Tanjungpinang $\left(\mathrm{R}^{2}=37.1 \%\right)$. These results are shown in Table 2. In Batam, agriculture sector has a coefficient 0.176 , which means if the credit of agriculture is raised $10 \%$, the economic growth of agriculture sector will raise $1.76 \%$.

If credit of industry sector is raised $10 \%$, the economic growth of industry will raise $2.47 \%$. If credit of building sector is raised $10 \%$, the economic growth of building will raise $1.45 \%$. If credit of trade, hotel, and restaurant sector is raised $10 \%$, the economic growth of trade, hotel, and restaurant will raise $2.21 \%$. If credit of transportation sector is raised $10 \%$, the economic growth of transportation will raise $3.01 \%$. And if credit of public service sector is raised $10 \%$, the economic growth of public services will raise $1.39 \%$.

In Tanjungpinang, agriculture sector has a coefficient
0.119 , which means if the credit of agriculture increase $10 \%$, the economic growth of agriculture sector will raise $1.19 \%$. If the credit of building sector increases $10 \%$, the economic growth of building will raise $1.65 \%$. If the credit of trade, hotel and restaurant sector raises $10 \%$, the economic growth of this sector will raise $5.32 \%$. If the credit of transportation sector raises $10 \%$, this economic growth based on this sector will increase $1.14 \%$. If the credit of services sector is raised $10 \%$, the economic growth of this sector will increase $1.63 \%$.

In this research, the number of observations are small. This is because the Province of Riau Archipelago is a province that is relatively new, so that the available data are still minimal.

In this study, time series data are need. Generally, its possible occurrence of autocorrelation. But from the results of data processing with Durbin-Watson test is concluded that there is no autocorrelation.

\section{CONCLUDING REMARKS}

Development based on national defense is the optimization of the development by considering all influencing factors. Prosperity and security approaches sustain the stability of all sectors. The combination of prosperity and security approaches is defined as the development based on defense system, safe from all threats, both from military and non military threats, so that sustainable development occurs.

Based on the model estimation step, the models which are built fit well for the data. It can be because of the coefficient of determination $\mathrm{R}^{2}$ that is more than $85 \%$. There are only 3 bad models (models with low $\mathrm{R}^{2}$ ), such as model for building sector in Batam $\left(\mathrm{R}^{2}=59.6 \%\right)$, model for building sector in Tanjungpinang $\left(\mathrm{R}^{2}=\right.$ $74.0 \%$ ), and model for sector of transportation and communication inTanjungpinang $\left(\mathrm{R}^{2}=37.1 \%\right)$.

Based on the elasticity, Batam's potential factor which should be developed in case of economic improvement is sector of transportation and communication $(\mathrm{E}=0.301)$. Then, in the second ranking, it is sector of industry $(\mathrm{E}=$ 0.247). In Tanjungpinang, the potential sector is sector of trade, hotel, and restaurant $(\mathrm{E}=0.532)$. In this research, the data used is not adequate to build spatial econometric model; therefore, the addition of other necessary variables is suggested.

\section{ACKNOWLEDGEMENT}

Research team gratefully acknowledges the financial support provided by DP2M DIRJEN DIKTI KEMENDIKNAS through Strategis Nasional 2009.

\section{REFERENCES}

[1] L. Anselin, 1988, "Spatial econometrics, methods and model, dardrecth, Icluwer Academic.

[2] BAPPENAS, 2007,"Penyusunan model perencanaan lintas wilayah dan lintas sektor.

[3] BPS, 2004, Kepulauan Riau Dalam Angka.

[4] BPS, 2005, Kepulauan Riau Dalam Angka.

[5] BPS, 2006, Kepulauan Riau Dalam Angka.

[6] BPS, 2007, Kepulauan Riau Dalam Angka.

[7] BPS, 2008, Kepulauan Riau Dalam Angka.

[8] BPS, 2008, GRDP Province of Archipelago of Riau.

[9] 2009, "Keynote speech Menteri Pertahanan in forkom litbang pertahanan in Umrah, Tanjungpinang, pp. 2. 
IPTEK, The Journal for Technology and Science, Vol. 21, No. 3, August 2010

[10] J. P. LeSage, 1999, "The theory and practice of spatial econometrics", Department Of Econometrics University of Toledo.
[11] D. M. M. Riyadi, 2000, "Model pembangunan ekonomi kepulauan Riau", Seminar Pengembangan Kepulauam Riau, Yogyakarta.

TABLE 1.

ECONOMIC GROWTH MODEL

\begin{tabular}{|c|c|c|c|}
\hline \multirow{2}{*}{$\begin{array}{l}\text { Region } \\
\text { Sector }\end{array}$} & \multirow{2}{*}{\multicolumn{3}{|c|}{ GRDP }} \\
\hline & & & \\
\hline \multicolumn{4}{|l|}{ Batam } \\
\hline Agriculture & $\mathrm{PDRBP}=10.4$ & \multicolumn{2}{|c|}{ KREDITP $=0.176$} \\
\hline Industries & PDRBI $=13.3$ & \multicolumn{2}{|c|}{ KREDITI $=0.247$} \\
\hline Buildings & $\mathrm{PDRBB}=10.9$ & \multicolumn{2}{|c|}{ KREDITB $=0.145$} \\
\hline Trades, hotels, restaurants & $\mathrm{PDRBD}=11.4$ & \multicolumn{2}{|c|}{ KREDITD $=0.221$} \\
\hline $\begin{array}{l}\text { Transportation and } \\
\text { communication }\end{array}$ & $\mathrm{PDRBB}=9.86$ & \multicolumn{2}{|c|}{ KREDITA $=0.301$} \\
\hline Services & $\mathrm{PDRBJ}=10.5$ & \multicolumn{2}{|c|}{ KREDITJ $=0.163$} \\
\hline \multicolumn{4}{|l|}{ Tanjungpinang } \\
\hline Agriculture & $\mathrm{PDRBP}=9.40$ & \multicolumn{2}{|c|}{ KREDITP= 0.119} \\
\hline Building & $\mathrm{PDRBB}=10.5$ & \multicolumn{2}{|c|}{ KREDITB $=0.165$} \\
\hline Trades, hotels, restaurants & $\mathrm{PDRBD}=5.80$ & \multicolumn{2}{|c|}{ KREDITD $=0.532$} \\
\hline $\begin{array}{l}\text { Transportation and } \\
\text { communication }\end{array}$ & $\mathrm{PDRBA}=11.4$ & \multicolumn{2}{|c|}{ KREDITB $=0.114$} \\
\hline Services & PDRBJ $=10.5$ & \multicolumn{2}{|c|}{ KREDITJ $=0.163$} \\
\hline \multicolumn{4}{|c|}{$\begin{array}{c}\text { TABLE } 2 . \\
\text { ELASTICITY AND R }{ }^{2}\end{array}$} \\
\hline Region - Sector & & & $\mathrm{R}^{2}$ \\
\hline \multicolumn{4}{|l|}{ Batam } \\
\hline 1. Agriculture & & 0.176 & 87.6 \\
\hline 2. Mining & & - & - \\
\hline 3. Industries & & 0.247 & 88.9 \\
\hline 4. Electricity, gas, and & vater & - & - \\
\hline 5. Building & & 0.145 & 59.6 \\
\hline 6. Trades, hotels, and $r$ & staurants & 0.221 & 97.6 \\
\hline 7. Transportation & & 0.301 & 96.0 \\
\hline 8. Monetary Insitution & & - & - \\
\hline 9. Services & & 0.139 & 98.6 \\
\hline \multicolumn{4}{|l|}{ Tanjungpinang } \\
\hline 1. Agriculture & & 0.119 & 92.7 \\
\hline 2. Mining & & - & - \\
\hline 3. Industries & & - & - \\
\hline 4. Electricity, gas, and & vater & - & - \\
\hline 5. Building & & 0.165 & 74.0 \\
\hline 6. Trades, hotels, and $\mathrm{r}$ & staurants & 0.532 & 99.4 \\
\hline 7. Transportation & & 0.114 & 37.1 \\
\hline 8. Monetary Insitution & & - & - \\
\hline 9. Services & & 0.163 & 99.9 \\
\hline
\end{tabular}


IPTEK, The Journal for Technology and Science, Vol. 21, No. 3, August 2010 